\title{
Genetics of hypogonadotropic hypogonadism
}

\author{
Adam C. Millar ${ }^{1,2}$, Hanna Faghfoury ${ }^{1,3}$, Jared M. Bieniek $^{4}$ \\ ${ }^{1}$ Department of Medicine, University of Toronto, Toronto, ON, Canada; ${ }^{2}$ Department of Medicine, Division of Endocrinology, Mount Sinai \\ Hospital and Toronto General Hospital, Toronto, ON, Canada; ${ }^{3}$ Department of Medicine, Fred A Litwin and Family Centre in Genetic Medicine, \\ Mount Sinai Hospital and Toronto General Hospital, Toronto, ON, Canada; ${ }^{4}$ Tallwood Urology \& Kidney Institute, Hartford HealthCare, \\ Hartford, CT, USA \\ Contributions: (I) Conception and design: AC Millar, JM Bieniek; (II) Administrative support: None; (III) Provision of study materials or patients: \\ None; (IV) Collection and assembly of data: All authors; (V) Data analysis and interpretation: All authors; (VI) Manuscript writing: All authors; (VII) \\ Final approval of manuscript: All authors. \\ Correspondence to: Adam C. Millar, MD. Division of Endocrinology and Metabolism, Mount Sinai Hospital, 60 Murray Street, $6^{\text {th }}$ Floor, Box 19 , \\ Toronto, ON, Canada. Email: Adam.millar@sinaihealth.ca.
}

\begin{abstract}
Male congenital hypogonadotropic hypogonadism $(\mathrm{CHH})$ is a heterogenous group of genetic disorders that cause impairment in the production or action of gonadotropin releasing hormone $(\mathrm{GnRH})$. These defects result in dysfunction of the hypothalamic-pituitary-gonadal hormone axis, leading to low testosterone levels and impaired fertility. Genetic testing techniques have expanded our knowledge of the underlying mechanisms contributing to $\mathrm{CHH}$ including over 30 genes to date implicated in the development of $\mathrm{CHH}$. In some cases, non-reproductive signs or symptoms can give clues as to the putative genetic etiology, but many cases remain undiagnosed with less than $50 \%$ identified with a specific gene defect. This leads to many patients labelled as "idiopathic hypogonadotropic hypogonadism". Medical and family history as well as physical exam and laboratory features can aid in the identification of hypogonadotropic hypogonadism $(\mathrm{HH})$ that is associated with specific medical syndromes or associated with other pituitary hormonal deficiencies. Genetic testing strategies are moving away from the classic practice of testing for only a few of the most commonly affected genes and instead utilizing next generation sequencing techniques that allow testing of numerous potential gene targets simultaneously. Treatment of $\mathrm{CHH}$ is dependent on the individual's desire to preserve fertility and commonly include human chorionic gonadotropin (hCG) and recombinant follicle stimulating hormone ( $\mathrm{rFSH})$ to stimulate testosterone production and spermatogenesis. In situations where fertility is not desired, testosterone replacement therapies are widely offered in order to maintain virilization and sexual function.
\end{abstract}

Keywords: Isolated hypogonadotropic hypogonadism; hypogonadism; hypopituitarism; congenital; infertility; male

Submitted Oct 20, 2019. Accepted for publication Mar 11, 2020.

doi: $10.21037 /$ tau.2020.03.33

View this article at: http://dx.doi.org/10.21037/tau.2020.03.33

\section{Background}

Estimates on prevalence of male hypogonadism vary greatly depending on the definition used to define low testosterone levels (1). Cases of hypogonadism can be broadly divided into primary (hypergonadotropic) hypogonadism, defined by low testosterone levels and reduced or absent sperm concentrations in the setting of elevated gonadotropin levels, and secondary (hypogonadotropic) hypogonadism
$(\mathrm{HH})$, defined by low testosterone levels and reduced or absent sperm concentrations in the setting of low or "inappropriately normal" gonadotropin levels. Each hypogonadal subtype can be further classified into acquired or congenital causes. While potentially one of the most treatable forms of male infertility, $\mathrm{HH}$ is a rare condition, representing $<1 \%$ of cases seen in fertility clinics (2).

Congenital hypogonadotropic hypogonadism $(\mathrm{CHH})$ is a heterogeneous group of inherited gene defects that 
Table 1 Associated phenotypic features of select gene mutations [adapted from references $(4,7)$ ]

\begin{tabular}{ll}
\hline Affected gene & Associated features \\
\hline ANOS1 (KAL1) & Cryptorchidism, small testes, may have unilateral renal agenesis, synkinesia (8) \\
SOX10 & $\begin{array}{l}\text { Waardenburg Syndrome: sensorineural deafness, skin, hair and iris pigmentation abnormalities, Hirschsprung's } \\
\text { disease (9) }\end{array}$ \\
IL17RD & Hearing loss (10) \\
TAC3 and TAC3R & Microphallus and cryptorchidism, potential reversibility of hypogonadism in adulthood (11) \\
FGFR1 & $\begin{array}{l}\text { Cleft lip or palate, dental agenesis, bimanual synkinesis, iris coloboma, possible agenesis of corpus callosum, } \\
\text { unilateral hearing loss, digital malformations (brachydactyly, syndactyly) (12) }\end{array}$ \\
FGF8 & Hearing loss, high arched palate, cleft lip/palate, severe osteoporosis, camplodactyly, digit hyperlaxity, microphallus, \\
& cryptorchidism, flat nasal bridge, hypertelorism (13) \\
CHARGE syndrome: coloboma of eye, heart defects, choanal atresia, retarded growth and development, genital & hypoplasia, dysmorphic ears and/or hypoplasia or aplasia of semicircular canals and deafness (14)
\end{tabular}

ultimately result in $\mathrm{HH}$. CHH has also been labelled in the literature as idiopathic hypogonadotropic hypogonadism, isolated hypogonadotropic hypogonadism or isolated gonadotropin-releasing hormone (GnRH) deficiency (3). For the purposes of this review, "CHH" will be used to describe $\mathrm{HH}$ due to diagnosed gene defects, while "isolated HH" will be reserved for cases in which a gene defect or other underlying etiology has not been identified.

$\mathrm{CHH}$ is recognized as having a male predominance, with estimates of male-to-female ratios ranging from 3-5 to 1 (4). Perhaps the most commonly recognized form of $\mathrm{CHH}$ is Kallmann syndrome, classically manifested by $\mathrm{HH}$ with lack of sense of smell (anosmia) or reduced sense of smell (hyposmia). Since the original description of Kallmann syndrome in 1944 (5), it has been recognized that there are a significant number of people with $\mathrm{CHH}$ who have a normal sense of smell. A Finnish study characterized the prevalence of Kallmann syndrome as representing 1 in 30,000 males and 1 in 125,000 females (6).

Although $\mathrm{CHH}$ is often grouped as one condition, it represents tremendous phenotypic and genotypic heterogeneity (Table 1). Patients can present with several non-reproductive signs and symptoms with over 30 genes implicated in genetic studies (3). There is significant variability in the inheritance patterns of $\mathrm{CHH}$, including autosomal dominant, autosomal recessive, $\mathrm{X}$-linked, and oligogenic inheritance, with further variations as a result of differences in gene penetrance and expressivity $(15,16)$.

It is interesting to note that despite the identification of nearly three dozen $\mathrm{CHH}$-related genes, a genetic etiology is still not identified in over $50 \%$ of cases (3), making $\mathrm{CHH}$ often a diagnosis of exclusion. Because of this, it is essential to rule out other possible causes of hypogonadotropic hypogonadism, such as pituitary tumors, infiltrative conditions such as hemochromatosis, other genetic syndromes, or functional hypogonadism caused by medications or other medical conditions before applying a label of CHH. In the adolescent patient, it is equally important to rule out the possibility of constitutional delay of growth and puberty (CDGP), which has been reported to be as high as $65 \%$ of males presenting with delayed pubertal onset (17).

\section{Pathophysiology}

Unlike other neuroendocrine cells, GnRH secreting neurons begin their development outside of the central nervous system in the medial part of the nasal epithelium, where they migrate to the forebrain starting in week 6 of embryonic development $(18,19)$. From here, the cells extend towards their ultimate locations in the arcuate nucleus and preoptic area of the hypothalamus. By week 15 of embryonic development the cells extend their axons towards the median eminence, where they can interact with the hypothalamo-pituitary portal vessels (3). GnRH, once secreted, enters the hypothalamo-pituitary portal vessels and travels to GnRH receptors located on gonadotropic cells in the anterior pituitary gland, ultimately binding to these receptors and resulting in secretion of luteinizing hormone ( $\mathrm{LH})$ and follicle stimulating hormone (FSH), and subsequent stimulation of various gonadal functions including testosterone production and spermatogenesis (4). 
Table 2 Subtypes of $\mathrm{CHH}$ [adapted from references $(4,7)$ ]

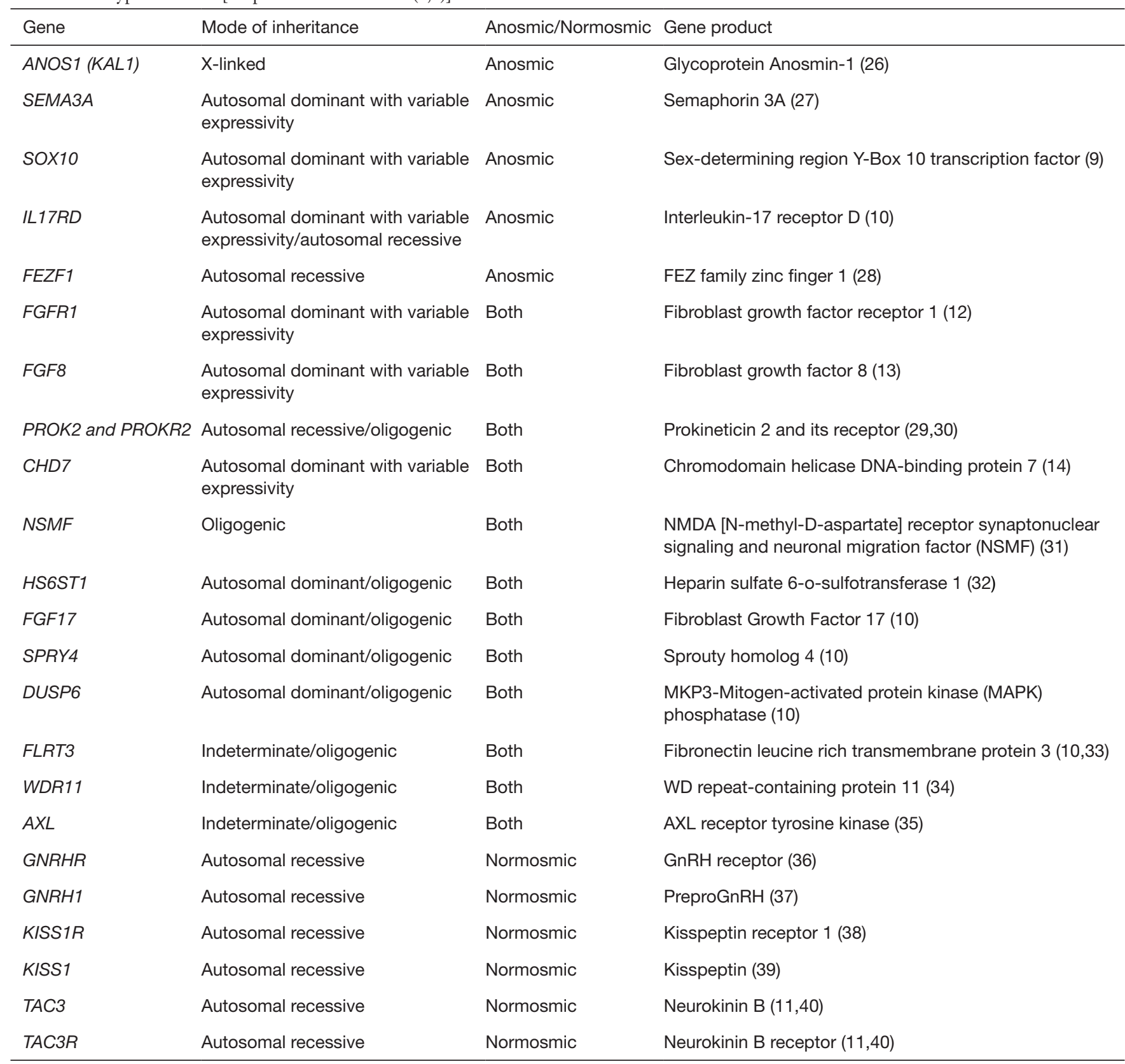

As olfactory neurons develop in close proximity to GnRH secreting neurons in the nasal placode and migrate along similar pathways, it can be understood how anosmia or hyposmia often occurs in conjunction with $\mathrm{CHH}(20,21)$. In many cases of Kallmann syndrome structural changes of the olfactory bulbs such as partial bulb development or complete aplasia can be visualized on brain MRI scans $(22,23)$. It should be noted, however, that a normal MRI scan does not rule out a diagnosis of Kallmann syndrome, as normal olfactory bulbs can still be visualized in $20 \%$ of cases $(24,25)$.

GnRH neuronal development is a complex process, with potential for defects at several stages of its course. As stated previously, nearly three dozen genes have been implicated in the development of $\mathrm{CHH}$, with examples listed in Table 2. It has been proposed by Young et al. that defects that occur 
during the development and migration of $\mathrm{GnRH}$ secreting neurons can ultimately lead to $\mathrm{CHH}$ via four broadly defined mechanisms:

(I) Defects in GnRH fate specification.

(II) Defects in GnRH neuron migration/olfactory neuron guidance.

(III) Abnormal neuroendocrine secretion/homeostasis.

(IV) Gonadotrope defects (3).

\section{Clinical presentation}

The presentation of individuals with $\mathrm{CHH}$ is dependent on the life stage at which the patient is assessed. Often the diagnosis is not made until adolescence, when lack of pubertal development may prompt further investigations. Neonatal boys with $\mathrm{CHH}$ may present earlier with micropenis and cryptorchidism due to a lack of GnRH stimulation (41). Signs and symptoms of $\mathrm{CHH}$ are more readily recognized during adolescence, though, as patients will demonstrate either partial or complete lack of secondary sexual characteristics, including absence of testicular and penile enlargement (42). Lack of pubertal progression is not diagnostic of $\mathrm{CHH}$ per se, as there are several other etiologies that must be considered (most notably CDGP). Affected individuals may also present later with concerns related to infertility, low libido, or erectile dysfunction (43).

Individuals with $\mathrm{CHH}$ can additionally present with nonreproductive symptoms and signs. Certain gene mutations known to cause isolated $\mathrm{HH}$ may predispose patients to other phenotypic changes that should prompt one to suspect a diagnosis of $\mathrm{CHH}$ (Table 1). Patients with classic Kallmann syndrome, for example, present with anosmia or hyposmia.

Distinguishing primary causes of isolated $\mathrm{HH}$ (i.e., $\mathrm{CHH}$ ) from secondary or syndromic causes of isolated $\mathrm{HH}$ can be a challenge. It may require careful history taking, close review of family history, biochemical workup and imaging studies. Physical examination can be helpful to identify physical features that point towards a syndromic cause.

There are other conditions that affect multiple endocrine pathways in addition to $\mathrm{HH}$. Individuals with obesity syndromes caused by mutations in PCSK1, LEP, and LEPR can develop HH (44-46). X-linked adrenal hypoplasia congenita caused by mutations in NROB1 (DAX1) not only demonstrate adrenal failure in early childhood but may also cause $\mathrm{HH}$ in young adulthood (47). Combined pituitary hormone deficiency caused by HESX1, LHX3,
LXH4, POU1F1, or PROP1 can result in various degrees of hypopituitarism with $\mathrm{HH}$ prior to the development of other endocrinological disturbances (48).

Further, chromosomal differences or other rare gene defects can predispose individuals to $\mathrm{HH}$ as part of larger syndromic diagnosis. The more common syndromes are outlined in Table 3 with their other associated features.

\section{Practical aspects to genetic testing and counseling}

\section{Genetic testing for $\mathrm{HH}$}

In the past, the recommended testing strategies prioritized the order of genetic testing based on clinical presentation (e.g., presence or absence of anosmia), testing of mutations with a higher detection rate (e.g., ANOS1), or by inheritance pattern. Next-generation sequencing technology is now available and has allowed for multiple genes to be sequenced efficiently and simultaneously as comprehensive $\mathrm{HH}$ genetic panels. As such, these historic testing strategies may not be rational or cost-effective. If after careful history taking, review of family history, laboratory workup and imaging studies a diagnosis of isolated $\mathrm{HH}$ is suspected, genetic testing should be considered.

Genetic testing in the form of a next-generation sequencing panel of genes associated with isolated $\mathrm{HH}$ is recommended (multiple genes sequenced simultaneously) unless there is a known familial mutation, a clear inheritance pattern in the family, or a specific feature that points towards specific causal genes. This should include at a minimum the common genes associated with Kallmann and normosmic HH including ANOS1, CHD7, FGFR1, GNRHR, IL17RD, PROKR2, SOX10, and TACR3. There are multiple genetic testing companies that offer genetic panels for $\mathrm{HH}$ that include the common genes noted above but also all of the rarer genes found in Tables 1 and 2, with variable but comparable costs. The benefit of a larger $\mathrm{HH}$ panel to include rare genes is the potential to detect a less common cause or contributor to $\mathrm{CHH}$, especially given the increasing number of $\mathrm{CHH}$ genes implicated in oligogenic disease. However, a possible downside of larger panels is the increased likelihood of detecting variants of unknown significance that may complicate genetic counselling of patients and families.

Any patient with developmental delay, and/or multiple congenital anomalies, and/or dysmorphic facial features should have chromosomal microarray testing to rule out copy 
Table 3 Common syndromes causing hypogonadotropic hypogonadism with their associated features

\begin{tabular}{|c|c|c|}
\hline Syndrome & Gene(s) & Associated features \\
\hline CHARGE syndrome & CHD7 & $\begin{array}{l}\text { Coloboma of eye, heart defects, choanal atresia, retarded growth } \\
\text { and development, genital hypoplasia, dysmorphic ears and/or } \\
\text { hypoplasia or aplasia of semicircular canals and deafness (14) }\end{array}$ \\
\hline $\begin{array}{l}\text { HFE-associated hereditary } \\
\text { hemochromatosis }\end{array}$ & HFE & Liver dysfunction, diabetes, cardiomyopathy, arthritis (50) \\
\hline Prader-Will syndrome & Loss of paternal $15 q 11.2$ & Obesity, developmental delay (51) \\
\hline TUBB3 E410K syndrome & TUBB3 & $\begin{array}{l}\text { Congenital fibrosis of extraocular muscles, facial weakness, } \\
\text { neuropathy, developmental delay (52) }\end{array}$ \\
\hline Waardenburg syndrome & SOX10 & $\begin{array}{l}\text { Sensorineural deafness, skin, hair and iris pigmentation } \\
\text { abnormalities, Hirschsprung's disease ( } 9 \text { ) }\end{array}$ \\
\hline Xp21 deletion syndrome & $\begin{array}{l}\text { Xp21 microdeletion encompassing } \\
\text { NROB1 }(D A X 1) \text { and } D M D\end{array}$ & $\begin{array}{l}\text { Primary adrenal insufficiency, Duchenne muscular dystrophy, } \\
\text { developmental delay, seizures, acidosis, hypoglycemia (54) }\end{array}$ \\
\hline Xp22.3 deletion syndrome & $\begin{array}{l}\text { Xp22.3 microdeletion encompassing } \\
\text { ANOS1 }\end{array}$ & Kallmann syndrome, chondrodysplasia punctate, and ichthyosis (3) \\
\hline
\end{tabular}

number variations and a referral to a clinical geneticist for evaluation and testing for possible syndromic causes of $\mathrm{HH}$.

\section{Genetic counseling for $\mathrm{HH}$}

Genetic testing can not only confirm a diagnosis and underlying etiology of $\mathrm{HH}$ but can be useful for genetic counseling and prognosis. Patients found to have a pathogenic variant (mutation) or variant(s) of unknown significance on an $\mathrm{HH}$ genetics panel should be referred to a genetics centre for review and appropriate counseling. Once a mutation is found in a gene causing $\mathrm{HH}$, the patient can be counseled appropriately with regards to risks to family members and future offspring.

ANOS1-related $\mathrm{CHH}$ is $\mathrm{X}$-linked and will thus preferentially affect males. A male with a mutation in ANOS1 has no chance of passing the condition on to male offspring, and his mother is eligible for carrier testing. All of his daughters will be obligate carriers for the condition and can potentially demonstrate features of hypogonadism, albeit less frequently. Autosomal conditions causing $\mathrm{HH}$ can affect males and females equally. In $\mathrm{HH}$ conditions that are autosomal dominant, there is a $50 \%$ risk of transmission to their offspring. Depending on the mutation status in parents, there can be an up to $50 \%$ risk to siblings as well. Most dominant forms of $\mathrm{HH}$ demonstrate reduced penetrance and variable expressivity. For recessive $\mathrm{HH}$ conditions, the risk of transmission to offspring is very low unless there is consanguinity. As mentioned previously, genetic counselling for individuals who carry mutations in different $\mathrm{CHH}$ genes causing oligogenic $\mathrm{HH}$ can be more challenging (55).

Genetic testing can also aid in prognostication and for personalized management of patients. For example, TAC3 and TAC3R mutations can cause $\mathrm{CHH}$ that may demonstrate reversibility in adulthood (11). Confirmation of a syndromic genetic diagnosis with potential features outside of the endocrine system (e.g., CHD7) may require additional screening and more complex medical management.

\section{Management}

Several treatment regimens exist for $\mathrm{CHH}$ with clinical 
decision making guided by treatment goals, specifically related to fertility, and patient preference. Treatments available for induction or replacement of testicular function include GnRH, gonadotropins [human chorionic gonadotropin (hCG) and recombinant FSH $(\mathrm{rFSH})]$, or testosterone replacement therapy (TRT). While TRT plays a role in inducing secondary sexual characteristics, administration of $\mathrm{GnRH}$ or gonadotropins are necessary to induce and support spermatogenesis (56). Given the challenges of administration and cost of $\mathrm{GnRH}$ and gonadotropins, peripubertal adolescent males with $\mathrm{CHH}$ are often initiated on TRT for puberty induction. Alternative treatment protocols must be considered once fertility is a concern. There are no standardized treatment regimens for $\mathrm{CHH}$, therefore the recommendations below are largely based on observational studies and expert opinion.

Young men with $\mathrm{CHH}$ ready to start a family often have been on TRT for several years following induction of puberty. Fortunately, fertility can be restored in most $\mathrm{CHH}$ men with physiologic-replicating protocols utilizing $\mathrm{GnRH}$ or gonadotropins. GnRH, when given in a pulsatile manner, stimulates release of natural FSH and LH from the anterior pituitary. Delivered via a subcutaneous pump, pulses of $25 \mathrm{ng} / \mathrm{kg}$ are delivered every $90-120 \mathrm{~min}$ (3). FSH/LH ratio varies based on $\mathrm{GnRH}$ dose thus pulse dosage is adjusted for the ideal physiologic response (57). Not available in many countries and requiring a high level of expertise, GnRH is rarely used outside of research settings.

Bypassing the pituitary, the testes of $\mathrm{CHH}$ men can be directly stimulated with gonadotropins. FSH is available in recombinant form as an injectable. LH is not commercially available but hCG can be substituted due to its comparable chemical structure. While hCG monotherapy is sufficient to induce androgen production in $\mathrm{CHH}$, it is less efficacious as a solitary puberty induction agent in $\mathrm{CHH}$ (58). Once fertility is a priority, $\mathrm{CHH}$ men should stop other androgen replacement protocols and initiate hCG subcutaneous injections of 500-1,500 IU three times weekly, adjusting dosage based on testosterone response (4). Side effects may include gynecomastia and erythrocytosis. Men with baseline severe testicular atrophy (volume $<4 \mathrm{~mL}$ ) or cryptorchidism should be counselled that hCG monotherapy has very low success rates and they will likely require a combination protocol $(4,59)$.

In men with no sperm at 3-6 months or low chances of fertility restoration with hCG monotherapy, $\mathrm{rFSH}$ should be added, starting at 75-150 IU subcutaneously three times weekly and adjusting dosage based on serum
FSH and sperm count. Despite possible dosage increases, it is apparent that testicular potential, namely volume and sperm production, may be limited in men with $\mathrm{CHH}$. Most reports suggest men with smaller testicular volumes pre-treatment will have smaller volumes posttreatment (58), and though spermatogenesis can be induced in most men (64-95\% in reported series), many will have oligospermia (3). A 2014 meta-analysis cited a mean sperm concentration of $5.9 \times 10^{6} / \mathrm{mL}$ following gonadotropin optimization (60). Promisingly, small series have suggested that the sperm concentration needed for conception among $\mathrm{CHH}$ men may be lower than World Health Organization reference values for fertile men (61). As gonadotropin treatment is continued, decreasing responsiveness to hCG may occur as a result of antibody induction (62).

FSH priming has received special attention in the literature. The rationale for this strategy stems from the fact that men with severe GnRH deficiency have a compromised Sertoli cell population which can be potentially optimized with $\mathrm{rFSH}$ before hCG. A single randomized controlled study of 13 young men demonstrated promising results with more patients in the treatment arm developing sperm in the ejaculate and trending towards higher sperm counts (63). All men had initial testicular volumes of $<4 \mathrm{~mL}$. Priming requires 2-4 months of initial $\mathrm{rFSH}$, an intensive and expensive protocol. Further studies are needed to determine the potential benefits and ideal $\mathrm{CHH}$ population for FSH priming.

Regardless of the testicular-stimulating protocol selection, sperm cryopreservation should be considered when found, even if fertility is not an active priority. Any sperm retrieved and frozen can be used later with assisted reproductive technologies (ART). Likewise, if spermatogenesis has been restored but a $\mathrm{CHH}$ man and his partner are unable to conceive naturally, referral should be made to a reproductive endocrinologist for complete female partner evaluation and ART discussion. Once done with family planning, most men with $\mathrm{CHH}$ will transition back to TRT.

Testosterone replacement can be accomplished with a variety of formulations including topical gels, nasal gel, patches, short and long-acting injectables, and pellets. Classic side effects of TRT includes skin changes (e.g., acne), gynecomastia, edema, infertility, worsening of obstructive sleep apnea and erythrocytosis. Effects on prostate and cardiac health remain controversial topics and are beyond the scope of the present review but should be 
discussed with patients. Topical options carry unique risk of transference to other individuals at home, a particular concern in $\mathrm{CHH}$ men who may have just started a family with the treatments noted above. Selection should be made based on patient preference, formulation-specific side effect profile, and availability.

\section{Conclusions}

Although $\mathrm{CHH}$ is a relatively uncommon cause of male infertility, it is one of the most treatable causes due to the availability and effectiveness of $\mathrm{GnRH}$ and gonadotropin replacement regimens. Ongoing advances in genetic testing and identification will hopefully lead to more men being diagnosed with a specific etiology thereby allowing targeted treatment options and informing requirements for genetic testing of family members and future offspring.

\section{Acknowledgments}

Funding: None.

\section{Footnote}

Provenance and Peer Review: This article was commissioned by the editorial office, Translational Andrology and Urology for the series "Genetic Causes and Management of Male Infertility". The article has undergone external peer review.

Conflicts of Interest: The authors have completed the ICMJE uniform disclosure form (available at http://dx.doi. org/10.21037/tau.2020.03.33). The series "Genetic Causes and Management of Male Infertility" was commissioned by the editorial office without any funding or sponsorship. JB served as the unpaid Guest Editor of the series. The authors have no other conflicts of interest to declare.

Ethical Statement: The authors are accountable for all aspects of the work in ensuring that questions related to the accuracy or integrity of any part of the work are appropriately investigated and resolved.

Open Access Statement: This is an Open Access article distributed in accordance with the Creative Commons Attribution-NonCommercial-NoDerivs 4.0 International License (CC BY-NC-ND 4.0), which permits the noncommercial replication and distribution of the article with the strict proviso that no changes or edits are made and the original work is properly cited (including links to both the formal publication through the relevant DOI and the license). See: https://creativecommons.org/licenses/by-nc-nd/4.0/.

\section{References}

1. Millar AC, Lau ANC, Tomlinson G, et al. Predicting low testosterone in aging men: A systematic review. CMAJ 2016;188:E321-30.

2. Hwang K, Walters RC, Lipshultz LI. Contemporary concepts in the evaluation and management of male infertility. Nat Rev Urol 2011;8:86-94.

3. Young J, Xu C, Papadakis GE, Acierno JS, et al. Clinical management of congenital hypogonadotropic hypogonadism. Endocr Rev 2019;40:669-710.

4. Boehm U, Bouloux PM, Dattani MT, et al. European consensus statement on congenital hypogonadotropic hypogonadism—pathogenesis, diagnosis and treatment. Nat Rev Endocrinol 2015;11:547-64.

5. Kallman, FJ, Schoenfeld, WA and Barrera, SE. The genetic aspects of primary eunuchoidism. Am J Metal Defic 1944;68:203.

6. Laitinen EM, Vaaralahti K, Tommiska J, et al. Incidence, phenotypic features and molecular genetics of Kallmann syndrome in Finland. Orphanet J Rare Dis 2011;6:41.

7. Stamou MI, Cox KH, Crowley WF Jr. Discovering genes essential to the hypothalamic regulation of human reproduction using a human disease model: adjusting to life in the "-omics" era. Endocr Rev 2016;2016:4-22.

8. Costa-Barbosa FA, Balasubramanian R, Keefe KW, et al. Prioritizing genetic testing in patients with Kallmann syndrome using clinical phenotypes. J Clin Endocrinol Metab 2013;98:E943-53.

9. Pingault $\mathrm{V}$, Bodereau $\mathrm{V}$, Baral $\mathrm{V}$, et al. Loss-of-function mutations in SOX10 cause Kallmann syndrome with deafness. Am J Hum Genet 2013;92:707-24.

10. Miraoui H, Dwyer AA, Sykiotis GP, et al. Mutations in FGF17, IL17RD, DUSP6, SPRY4, and FLRT3 are identified in individuals with congenital hypogonadotropic hypogonadism. Am J Hum Genet 2013;92:725-43.

11. Gianetti E, Tusset C, Noel SD, et al. TAC3/TACR3 mutations reveal preferential activation of gonadotropinreleasing hormone release by neurokinin B in neonatal life followed by reversal in adulthood. J Clin Endocrinol Metab 2010;95:2857-67.

12. Dodé C, Levilliers J, Dupont JM, et al. Loss-of-function mutations in FGFR1 cause autosomal dominant Kallmann syndrome. Nat Genet 2003;33:463-5.

13. Falardeau J, Chung WC, Beenken A, et al. Decreased FGF8 signaling causes deficiency of gonadotropin- 
releasing hormone in humans and mice. J Clin Invest 2008; 118:2822-31.

14. Jongmans MCJ, Admiraal RJ, van der Donk KP, et al. CHARGE syndrome: the phenotypic spectrum of mutations in the CHD7 gene. J Med Genet 2006;43:306-14.

15. Pitteloud N, Quinton R, Pearce S, et al. Digenic mutations account for variable phenotypes in idiopathic hypogonadotropic hypogonadism. J Clin Invest 2007;117:457-63.

16. Sykiotis GP, Plummer L, Hughes VA, et al. Oligogenic basis of isolated gonadotropin-releasing hormone deficiency. Proc Natl Acad Sci U S A 2010;107:15140-4.

17. Sedlmeyer IL, Palmert MR. Delayed puberty: analysis of a large case series from an academic center. J Clin Endocrinol Metab 2002;87:1613-20.

18. Teixeira L, Guimiot F, Dode C, et al. Defective migration of neuroendocrine GnRH cells in human arrhinencephalic conditions. J Clin Invest 2010;120:3668-72.

19. Schwanzel-Fukuda M, Crossin KL, Pfaff DW, et al. Migration of Luteinizing Hormone-Releasing Hormone (LHRH) neurons in early human embryos. J Comp Neurol 1996;366:547-57.

20. Schwanzel-Fukuda M, Bick D, Pfaff DW. Luteinizing hormone-releasing hormone (LHRH)-expressing cells do not migrate normally in an inherited hypogonadal (Kallmann) syndrome. Brain Res Mol Brain Res 1989;6:311-26.

21. Wray S, Grant P, Gainer H. Evidence that cells expressing luteinizing hormone-releasing hormone mRNA in the mouse are derived from progenitor cells in the olfactory placode. Proc Natl Acad Sci U S A 1989;86:8132-6.

22. Truwit CL, Barkovich AJ, Grumbach MM, et al. MR imaging of Kallmann syndrome, a genetic disorder of neuronal migration affecting the olfactory and genital systems. AJNR Am J Neuroradiol 1993;14:827-38.

23. Sato N, Katsumata N, Kagami M, et al. Clinical assessment and mutation analysis of Kallmann syndrome 1 (KAL1) and fibroblast growth factor receptor 1 (FGFR1, or KAL2) in five families and 18 sporadic patients. J Clin Endocrinol Metab 2004;89:1079-88.

24. Silveira LF, MacColl GS, Bouloux PM. Hypogonadotropic hypogonadism. Semin Reprod Med 2002;20:327-38.

25. Mitchell AL, Dwyer A, Pitteloud N, et al. Genetic basis and variable phenotypic expression of Kallmann syndrome: towards a unifying theory. Trends Endocrinol Metab 2011;22:249-58.

26. de Castro F, Seal R, Maggi R, on behalf of Group of HGNC consultants for KAL1 nomenclature. ANOS1: a unified nomenclature for Kallmann syndrome 1 gene (KAL1) and anosmin-1. Brief Funct Genomics 2017;16:205-10.

27. Messina A, Giacobini P. Semaphorin signaling in the development and function of the gonadotropin hormonereleasing hormone system. Front Endocrinol (Lausanne) 2013;4:133.

28. Kotan LD, Hutchins BI, Ozkan Y, et al. Mutations in FEZF1 cause Kallmann syndrome. Am J Hum Genet 2014;95:326-31.

29. Pitteloud N, Zhang C, Pignatelli D, et al. Loss-offunction mutation in the prokineticin 2 gene causes Kallmann syndrome and normosmic idiopathic hypogonadotropic hypogonadism. Proc Natl Acad Sci U S A 2007;104:17447-52.

30. Cole LW,Sidis Y, Zhang C, et al. Mutations in prokineticin 2 and prokineticin receptor 2 genes in human gonadotrophin- releasing hormone deficiency: molecular genetics and clinical spectrum. J Clin Endocrinol Metab 2008;93:3551-9.

31. Miura K, Acierno JS Jr, Seminara SB. Characterization of the human nasal embryonic LHRH factor gene, NELF, and a mutation screening among 65 patients with idiopathic hypogonadotropic hypogonadism (IHH). J Hum Genet 2004;49:265-8.

32. Tornberg J, Sykiotis GP, Keefe K, et al. Heparan sulfate 6-O-sulfotransferase 1, a gene involved in extracellular sugar modifications, is mutated in patients with idiopathic hypogonadotrophic hypogonadism. Proc Natl Acad Sci U S A 2011;108:11524-9.

33. Lacy SE, Bönnemann CG, Buzney EA et al. Identification of FLRT1, FLRT2, and FLRT3: a novel family of transmembrane leucine-rich repeat proteins. Genomics 1999;62:417-26.

34. Kim, HG, Ahn JW, Kurth I., et al. WDR11, a WD protein that interacts with transcription factor EMX1, is mutated in idiopathic hypogonadotropic hypogonadism and Kallmann syndrome. Am. J. Hum. Genet 2010;87:465-79.

35. Salian-Mehta S, Xu M, Knox AJ, et al. Functional consequences of AXL sequence variants in hypogonadotropic hypogonadism. J Clin Endocrinol Metab 2014;99:1452-60.

36. de Roux N, Young J, Misrahi M, et al. A family with hypogonadotropic hypogonadism and mutations in the gonadotropin releasing hormone receptor. N Engl J Med 1997;337:1597-602.

37. Chan YM, de Guillebon A, Lang-Muritano M, et al. GNRH1 mutations in patients with idiopathic hypogonadotropic hypogonadism. Proc Natl Acad Sci U S A 2009;106:11703-8. 
38. de Roux N, Genin E, Carel JC, et al. Hypogonadotropic hypogonadism due to loss of function of the KiSS1derived peptide receptor GPR54. Proc Natl Acad Sci U S A 2003;100:10972-6.

39. Topaloglu AK, Tello JA, Kotan LD, et al. Inactivating KISS1 mutation and hypogonadotropic hypogonadism. N Engl J Med 2012;366:629-35.

40. Topaloglu AK, Reimann F, Guclu M, et al. TAC3 and TACR3 mutations in familial hypogonadotropic hypogonadism reveal a key role for Neurokinin B in the central control of reproduction. Nat Genet 2009;41:354-8.

41. Kaplan JD, Kwan A, Bernstein JA, et al. Clues to an early diagnosis of Kallmann syndrome. Am J Med Genet Part A 2010;152A:2796-801.

42. Palmert MR, Dunkel L. Delayed Puberty. N Engl J Med 2012;366:443-53.

43. Silveira LF, Latronico AC. Approach to the patient with hypogonadotropic hypogonadism. J Clin Endocrinol Metab 2013;98:1781-8.

44. Jackson RS, Creemers JW, Farooqi IS, et al. Smallintestinal dysfunction accompanies the complex endocrinopathy of human proprotein convertase 1 deficiency. J Clin Invest 2003;112:1550-60.

45. Strobel A, Issad T, Camoin L, et al. A leptin missense mutation associated with hypogonadism and morbid obesity. Nat Genet 1998;18:213-5.

46. Clément K, Vaisse C, Lahlou N, et al. A mutation in the human leptin receptor gene causes obesity and pituitary dysfunction. Nature 1998;392:398-401.

47. Hay ID, Smail PJ, Forsyth CC. Familial cytomegalic adrenocortical hypoplasia: an X-linked syndrome of pubertal failure. Arch Dis Child 1981;56:715-21.

48. Fang Q, George AS, Brinkmeier ML, et al. Genetics of combined pituitary hormone deficiency: roadmap into the genome era. Endocr Rev 2016;37:636-675.

49. Baker K, Beales PL. Making sense of cilia in disease: the human ciliopathies. Am J Med Genet C Semin Med Genet 2009;151C:281-95.

50. Allen KJ, Gurrin LC, Constantine CC, et al. Iron-overload-related disease in HFE hereditary hemochromatosis. N Engl J Med 2008;358:221-30.

51. Eldar-Geva T, Hirsch HJ, Benarroch F, et al. Hypogonadism in females with Prader-Willi syndrome from infancy to adulthood: variable combinations of a primary gonadal defect and hypothalamic dysfunction. Eur J Endocrinol 2010;162:377-84.

52. Chew S, Balasubramanian R, Chan WM, et al. A novel syndrome caused by the $\mathrm{E} 410 \mathrm{~K}$ amino acid substitution in the neuronal beta-tubulin isotype 3 .
Brain 2013;136:522-35.

53. Warburg M, Sjo O, Fledelius HC, et al. Autosomal recessive microcephaly, microcornea, congenital cataract, mental retardation, optic atrophy, and hypogenitalism. Micro syndrome. Am J Dis Child 1993;147:1309-12.

54. Wikiera B, Jakubiak A, Zimowski J, et al. Complex glycerol kinase deficiency-X-linked contiguous gene syndrome involving congenital adrenal hypoplasia, glycerol kinase deficiency, muscular Duchenne dystrophy and intellectual disability (IL1RAPL gene deletion) Pediatr Endocrinol Diabetes Metab 2012;18:153-7.

55. Au MG, Crowley WF Jr, Buck CL. Genetic counseling for isolated GnRH deficiency. Mol. Cell. Endocrinol 2011;346:102-9.

56. Delemarre-Van de Waal HA. Induction of testicular growth and spermatogenesis by pulsatile, intravenous administration of gonadotrophin-releasing hormone in patients with hypogonadotrophic hypogonadism. Clin Endocrinol (Oxf) 1993;38:473-80.

57. Wentz AC. Clinical applications of luteinizing hormonereleasing hormone. Fertil Steril 1977;28:901-12.

58. Delemarre EM, Felius B, Delemarre-van de Waal HA. Inducing puberty. Eur. J. Endocrinol 2008;159:S9-S15.

59. Swee DS, Quinton R. Managing congenital hypogonadotrophic hypogonadism: a contemporary approach directed at optimizing fertility and longterm outcomes in males. Ther Adv Endocrinol Metab 2019;10:2042018819826889.

60. Rastrelli G, Corona G, Mannucci E, et al. Factors affecting spermatogenesis upon gonadotropin-replacement therapy: a meta-analytic study. Andrology 2014;2:794-808.

61. Burris AS, Clark RV, Vantman DJ, et al. A low sperm concentration does not preclude fertility in men with isolated hypogonadotropic hypogonadism after gonadotropin therapy. Fertil Steril 1988;50:343-7.

62. Thau RB, Goldstein M, Yamamoto Y, et al. Failure of gonadotropin therapy secondary to chorionic gonadotropin-induced antibodies. J Clin Endocrinol Metab 1988;66:862-7.

63. Dwyer AA, Sykiotis GP, Hayes FJ, et al. Trial of recombinant follicle-stimulating hormone pretreatment for $\mathrm{GnRH}$-induced fertility in patients with congenital hypogonadotropic hypogonadism. J Clin Endocrinol Metab 2013;98:E1790-5.

Cite this article as: Millar AC, Faghfoury H, Bieniek JM. Genetics of hypogonadotropic hypogonadism. Transl Androl Urol 2021;10(3):1401-1409. doi: 10.21037/tau.2020.03.33 